\title{
A Review of Women Empowerment, its Measurement and Dimensions Promoting the Self Reliance of Livestock Based Households in India
}

\author{
Jagruti Das $^{{ }^{*}}$, Ajmer Singh ${ }^{1}$ and Aniketa Horo ${ }^{3}$ \\ ${ }^{1}$ Division of Economics, Statistics and Management, ICAR-NDRI, Karnal, Haryana-132001 \\ ${ }^{2}$ Department of Economics and Sociology, Punjab Agricultural University, \\ Ludhiana-141004, India \\ *Corresponding author
}

\section{A B S T R A C T}

Keywords

Women

empowerment,

Livestock sector,

Feminization

\section{Article Info}

Accepted:

17 August 2020

Available Online:

10 September 2020
The empowerment of women and girl child is smart economics and therefore has become a part and parcel of developmental goals all over the world. In India, the potentialities of women are not realized properly due to social structure and stigmas which hamper their development in particular and the development of the society in general. In India, the trend of feminization of livestock production, dairy and animal husbandry stemmed long back even before Operation Flood around the 1970s. Women nearly comprise of $70 \%$ of the workers, $80 \%$ of food producers, and $10 \%$ of basic food stuff processors pertaining to the dairy sector alone (Patel, 1998). The role of women within the livestock production system differs from region to region influenced by social, cultural and economic factors which when assessed properly could help to incentivize the above mentioned aspects (Patel et.al, 2016). This paper reviews the role of dairy sector in enhancing the economic status of rural women and in turn empowering them.

\section{Introduction}

Women empowerment is the end and method of developing a woman's capacity to be independently developing her sense of inner strength. The livestock sector predominantly dairying in India is a female dominated enterprise. It is established beyond doubt that women always participated in dairy and animal husbandry activities in addition to their daily household chores as a part and parcel of their daily lives. Women spend more time than men in livestock based production activities but their share in the income derived from the enterprise is much lesser. The major credit for India's position as the highest milk 
producer and subsequent increase in per capita availability of milk has to be given to millions of rural women dairy farmers. In recent decades, the dairy and animal husbandry sector has emerged as an important source of rural employment and income in the country providing employment to the rural women in their household premises. Income from dairying contributes nearly a third of the rural households' gross income and in the case of landless wage earning households, nearly a half (Pankaj et al., 2005). The current article reviews women empowerment and its dimensions in the livestock sector in general which promotes self reliance of the rural women.

\section{Women empowerment: Definition}

A review into the literature reflects considerable diversity in the emphases, agendas, and terminologies used to define women empowerment. Even though, there is no single definition of women empowerment in the literature, it can be variously summarized as a process or outcome, an end state or a means to an end, a capacity (Kabeer, 2001; Malhotra et al., 2002; Martinez, 2006), a matter of gaining power, and as a matter of agency (Kabeer, 1999; Narayan, 2005). Many studies (Kabeer, 2001; Oxaal and Baden, 1997) have defined empowerment as the process of getting over the factors which cause powerlessnes. Kabeer (2001), whose definition is the best accepted, defines empowerment as the expansion of ability of the people to make strategic life choices where this ability was previously denied to them. Bennett (2002) described women empowerment as enhancement of assets and capabilities of individuals and groups to engage influence and hold accountable the institutions which affect them. Keller and Mbwewe (1991) described women empowerment as a process wherein women become able to increase their own self reliance, to assert their rights, to make choices and to control resources which will assist in reducing their own subordination. Rowland (1997) defined women empowerment as a dynamic process aiming itself at finding more space for control and to encompass change at the personal and collective level.

\section{Women empowerment: Need and origin}

Women are major flag bearers in ensuring household wellbeing in the rural areas of most developing countries of South-east Asia including India. The ability to improve the livelihoods of their households is hampered because they are disempowered economically, socially, in agriculture and in civic arenas. Women need more access and control of resources, which together constitute the empowerment capabilities leading to improvement in their livelihoods. Thus, women empowerment is considered important to provide them with the means to meet their needs and desired livelihood outcomes. On the other hand, women with higher of sociocultural restrictions to agriculture are less likely to have food secure households. In addition to it being an end goal in itself, women empowerment is also considered as a means to achieve other important livelihood outcomes such as more income, increased well-being (e.g., non-material goods, like selfesteem, health status, access to services, sense of inclusion), reduced vulnerability, improved food security and a more sustainable use of natural resources (e.g., appropriate property rights), improvements in child nutritional status, and self-reliance.

\section{Empowerment of women in the world and India}

In 1985 at the International Women's Conference at Nairobi, women empowerment was initially introduced as a concept. It was concluded in the conference that empowerment is a rearrangement of power and control of resources in support of woman 
through positive intervention. The functioning of women empowerment is considered to be very significant for the progress of the future of India. In order to focus a vision where women are equal to men, the year 2001 had been stated as 'Women Empowerment Year' by the Government of India. India is considered to be one of the fastest growing countries in the world. It has been further observed that the growth of any nation is extensively influenced and determined by the status and development of woman.PM Jawaharlal Nehru once said, "Women should be uplifted for the betterment of the nation, if a woman is uplifted, society and nation is uplifted." To reduce the poverty and assist in development empowerment is the key goal. As a result, the mid- 1980s, observed the emergence and spread of women's empowerment. As per the view point of thinkers, empowerment is a socio-political method that needs shifts in political, social, and economic power between and across both individuals and social groups.

\section{Women empowerment and livestock sector in India}

"For a woman, empowerment is not just the extra money; it's not just the bank account balance and not at all the way out of domestic drudgery and responsibilities. The key credit for India's status as highest milk producer and subsequent increase in per capita availability of milk can be attributed to the illiterate rural women dairy farmers (Patel, 1998)." Livestock farming as an enterprise does not require heavy capital investments due to which rural women can begin one with the available non-descript cows or with animals purchased from local markets. The local animals have more endurance, low maintenance and hence can be maintained even by landless rural women. Livestock raising us not much of a labour demanding activity even and hence can be easily undertaken without altering the present way of life. Table 1 depicting the willingness of the Indian rural women to work within the household premises, it can be seen that the most preferred sector to accept work among the rural women and weighs more in terms of full time and part time participation are livestock and food processing activities.

\section{Measurement of Women Empowerment: Women Empowerment in Agriculture Index (WEAI)}

Measurement and quantification of empowerment has been done differently by various scholars because processes of empowerment and exercise of agency cannot be easily observed, because of which proxy indicators are often used for measurement. The challenge that comes with using proxy measures is that they do not provide much information on the "decision making dynamics or mechanisms of where causality is often ambiguous, these measures are therefore better defined as correlates or indirect measures of empowerment rather than determinants (Malhotra et al., 2002). Several studies have attempted to measure women's empowerment in agriculture. One significant effort towards this has been the development of Women's Empowerment in Agriculture Index (WEAI) by the US government's Feed the Future Initiative in 2012. The WEAI focuses on the "agency" aspect, which is far less studied than resources such as income, or achievements such as educational levels (Alkire et al., 2013). The WEAI also departs from previous measures of women's empowerment in that it captures control over resources or agency within the agricultural sector, something which existing indices have not done. It is an aggregate index that shows the degree to which women are empowered in their households and communities and the degree of inequality between women and men in the 
household (Alkire et al., 2012). In 2015, IFPRI and Feed the Future released an abbreviated version of the WEAI that has a shorter interview time and removes four subareas of the original WEAI that were either too subjective or too confusing for enumerators to collect.

\section{Dimensions and sub-dimensions of women empowerment}

The report of World Bank on "Engendering Development" (2001) which proves that the rights, resources, and voice as the three vital gears of gender equality. Women empowerment is a multidimensional and complex process that captures a multitude of constructs. The dimensions of women empowerment are dynamic, interlinked and mutually reinforcing, hence women empowered in one dimension, may not necessarily be empowered in another (Kabeer, 1999; Malhotra et al., 2002). Hence, the identification of the dimensions in which women are empowered or disempowered allows empowerment agencies in developing countries, to be more effective in designing interventions thereby raising the standard of living for rural women and their families. Many studies have used PCA to measure the dimensions of women empowerment (Gupta and Yesudian, 2006), the multidimensional approach ( Malhotra et al., 2002; Kabeer, 1999) and the resource-agency-outcome approach as used by Kabeer (1999) for coming up with various dimensions of women's empowerment. A list of the most commonly used dimensions of women's empowerment has been synthesised from the multidimensional approach suggested by Malhotra et al., (2002) and Kabeer (1999) and the resource-agency-outcome approach (Kabeer, 1999). The multidimensional framework suggests that rural women's empowerment occurs along the following dimensions and their sub-dimensions: economic ( physical capital, human capital, natural capital, and financial capital empowerment), socio capital, -cultural (social familial/interpersonal, organizational, cultural and informational empowerment), agricultural (access to agricultural resources, crop production skills, animal husbandry skills, water-use security levels) and civic forms of empowerment (legal, political, and psychological).

\section{Dimensions and sub-dimensions of women empowerment promoting self- reliance}

Self-reliance is defined as a state of mind that regards one's own mental and material resources as the primary stock to draw on, in pursuit of one's objectives, and finds emotional fulfillment not only in achieving the objectives but of having achieved them primarily by using one"s own resources which instills a sense of self confidence and thereby encourages in taking up of new ventures. It is the social and economic ability of an individual, household or community to meet basic needs (including protection, food, water, shelter, personal safety, health and education) using their own resources in a sustainable manner and with dignity (UNHCR, 2011). Self-reliance is thus, development on the basis of a country's, household's or individual's own resources, based on the potential of the cultural values and traditions. According to Haque et al., (2012) and Keller and Mbwewe (1991) the core outcome of women's empowerment lies in their ability to control their destiny and be self-reliant. Hence, selfreliance is an integral outcome of women empowerment, since; ideally, development should foster self-reliance (Binns and Nel, 1999). Therefore, women empowerment (i.e., women's access and control over resources and their agency) is a pre-requisite to achieve self-reliance. Women depending more on farm and off-farm livelihoods for income lies within the UNHCR (2011)'s conceptualized 
definition of self-reliance since they had a higher capacity to meet their basic needs using own resources in a sustainable and dignified manner. Therefore, women in this category were considered the most self-reliant as they used their own capabilities to achieve livelihood outcomes.

Table.1 Willingness to accept work by the rural women among different related enterprises

\begin{tabular}{|l|c|c|c|c|}
\hline Type of work acceptable & \multicolumn{2}{|c|}{ Regular } & Occasional & All \\
\hline & Full time & Part time & & \\
\hline Dairy & 215 & 755 & 30 & 1000 \\
\hline Poultry & 186 & 780 & 34 & 1000 \\
\hline Other animal husbandry & 217 & 747 & 36 & 1000 \\
\hline Food Processing & 178 & 748 & 73 & 1000 \\
\hline
\end{tabular}

Source: NSS Report No. 559: Participation of Women in Specified Activities in tune with Domestic Duties

In conclusion, widening of women's economic opportunities means: more and better jobs for women across a wider range of sectors; an environment that supports women in being independent, and building their management and entrepreneurial skills; a financial sector in which commercial banks and microfinance institutions provide women with effective access to a range of financial services and products tailored to their needs, including credit and savings instruments; and, in times of high food and fuel prices, greater livelihood security for women, especially in rural areas and vulnerable environments. In view of the critical role of women in the agriculture and allied sectors, as producers, concentrated efforts should be made to ensure that benefits of training, extension such that the various programmes will reach them in proportion to their numbers even at the grass root levels. The programmes for training women in soil conservation, social forestry, dairy development and other occupations allied to agriculture like horticulture, livestock including small animal husbandry, poultry, fisheries etc. will be expanded to benefit women workers in the agriculture sector. Women empowerment has a positive bearing on the household food and nutritional security which could be utilized in framing policies and programmes which would target women to ensure household food and nutritional security and thereby ensuring enhanced livelihood of the household.

\section{References}

Alkire S, Meinzen-Dick R, Peterman A, Quisumbing AR, Seymour G and Vaz A. (2012). The Women's Empowerment in Agriculture Index'. IFPRI Discussion Paper 01240 December 2012. The International Food Policy Research Institute (IFPRI) http://www.ifpri.org/sites/default/files/publi cations/ifpridp01240.pdf.

Alkire S, Meinzen-dick R, Peterman A, Quisumbing A, Seymour G and Vaz A. (2013). The Women's Empowerment in Agriculture Index. World development, 52: 71-91.

Bennett L. (2002). Using empowerment and social inclusion for pro-poor growth: a theory of social change. working draft of background paper for the social development strategy paper. Washington, DC: World Bank.

Binns T and Nel E (1999). Beyond the development impasse: the role of local economic development and community self-reliance in rural South Africa. The Journal of Modern African Studies 37 (3): 
389-408.

Gupta K and Yesudian PP. (2006). Evidence of women's empowerment in India: a study of socio-spatial disparities. Geo Journal 65: 365-380.

Haque M, Islam TM, Tareque I and Mostofa G . (2011). Women Empowerment or Autonomy: A Comparative View in Bangladesh Context. Bangladesh e-Journal of Sociology 8 (2): 1730.

Kabeer N. (1999). Resources, Agency, Achievements: Reflection on the measurement of women's empowerment. Development and Change 30(3): 435-464.

Kabeer N. (2001). Reflections on the Measurement of Women's EmpowermentTheory and Practice. In Discussing Women's Empowerment-Theory and Practice, edited by A. Sisask, 17-54.

Keller B and Mbwewe DC. (1991). Policy and planning for the empowerment of Zambia's women farmers. Canadian Journal of Development Studies 12(1):75-88

Malhotra A, Schuler SR and Boender C. (2002). Measuring Women's Empowerment as a Variable in International Development. Background Paper Prepared for the World Bank Workshop on Poverty and Gender: New Perspectives.

Martinez E. (2006). The Courage to Change: Confronting the limits and unleashing the potential of CARE's programming for women. Synthesis Report: Phase 2. CARE International Strategic Impact Inquiry on Women's Empowerment', CARE International

http://pqdl.care.org/sii/SIILibrary/SII\%20W omen $\% 27 \mathrm{~s} \%$.

Narayan D. (2005). Measuring empowerment: Cross disciplinary perspective. The International Bank for Reconstruction and
Development / The World Bank, 1818 H Street, NW Washington, DC 20433. https://openknowledge.

Worldbank.org/bitstream/handle/ 10986/7441

/344100PAPER0Me101Official0use

0only1.pdf? sequence $=1$.

National Sample Survey Organization. (2011). Employment and unemployment in India, 2009-10.NSS $66^{\text {th }}$ Round-Key Indicators of employment and unemployment in India 2009-2010 (Report No. 537). Ministry of Statistics and Programme Implementation, Government of India, New Delhi.

Oxaal Z and Baden S. (1997). Gender and empowerment: definitions, approaches and implications for policy. Bridge Report No. 40. Sussex: Institute of Development Studies.

Pankaj, P.K., Singh, A., Roy, B. (2005). Animal husbandry and dairying, Kurukshetra. 52(12), 10-12

Patel, A. (1998). Women and white revolution. Cooperative Dialogue. 8(1),20-25.

Patel, S.J., Patel, M.D., Patel, J.H., Patel, A.S., and Gelani, R.N. (2016). Role of women gender in the livestock sector: A review. Journal of Livestock Science. 7, 92-96.

Rowlands J. (1995). Empowerment Examined, Development in Practice, pp. 101-107. http://www.informaworld.

$\mathrm{com} / \mathrm{smpp} /$ content $\sim$ content $=\mathrm{a} 71366081$ $0 \sim \mathrm{db}=$ all.

UNHCR.(2011).Promoting Livelihoods and Selfreliance Operational Guidance on Refugee Protection and Solutions in Urban Areas. United Nations High Commissioner for Refugees. OSTS / Livelihood unit, Rue de Montbrillant

\section{How to cite this article:}

Jagruti Das, Ajmer Singh and Aniketa Horo. 2020. A Review of Women Empowerment, its Measurement and Dimensions Promoting the Self Reliance of Livestock Based Households in India. Int.J.Curr.Microbiol.App.Sci. 9(09): 2041-2046. doi: https://doi.org/10.20546/ijcmas.2020.909.254 